\title{
QUO VADIS, OPVOEDER.
}

Mens kan nie help om op die vooraand van die Republiek ernstig aan die dink te gaan oor die toekomstaak wat daar vir ons op elke terrein wag nie. Daarom kry ons dan ook orals die spekulasies van politici, van spesialiste op verskillende terreine, van swartgalliges en supra-optimiste, van heils- en onheilsprofete. Op die opvoedkundige terrein ontbreek hierdie spekulasies ook nie. Daar is egter geeneen van hulle wat nie vir ans baie waardevol kan wees nie: die onheilsprofete mag te swartgallig wees maar hulle vestig beslis ons aandag op tendense wat gevare inhou; die optimis- te wat van die nuwe bedeling niks anders as rose en maanskyn verwag nie, herinner ons aan die idealisme waarmee alle opvoeders besiel moet wees om in hulle taak te slaag. Opvoedkundiges skrywe oor hierdie dinge in die opvoedkundige sowel as in die lekepers. Ons wil hier slegs op 'n paar aspekte van hulle probleme let.

Daar is weinig konkreets waarop hierdie spekulasies hulle kan rig. Die voorgestelde Nasionale Onderwysraad is egter 'n uitsondering op hierdie reël. Dit dien dikwels as die spil waar die spekulasies om wentel. Deur een seksie 
van die opvoedkundiges word dit nou voorgehou as die paaiboelie waarmee almal banggemaak word. Hierdie Raad sal dan seksioneel saamgestel word en sal daarom slegs seksionele belange dien. Hy sal die middel wees om Engels (en al die Engelse op die koop toe) van die Suid-Afrikaanse toneel weg te vee. As 'n dwingeland sal hy verder die sendingarm van die drie Afrikaanse kerke wees om almal tot daardie godsdiens te bekeer. So word agterdog teen 'n ding wat nog nie eers bestaan nie, gesaai in 'n poging om die werk daarvan te verydel. Hier is ' $n$ duidelike geval van iemand wat weier om hand in eie boesem te steek en sodoende die bron van eie swakheid en vrees te ontdek. $\mathrm{Al}$ is hierdie mense besig om hulle eie ondergang te bewerk, kan die Raad nou die skuld vir enige agteruitgang kry.

Aan die ander pool staan weer baie opvoedkundiges wat ewe seer weier om die hand in eie boesem te steek, nie omdat hulle bang is dat hulle die kwaad daar sal ontdek nie: hulle weet die kwaad is daar maar hulle weier om dit aan te durf. Die Onderwysraad moet nou met 'n plan en wetgewing kom wat die kwaad sal uitroei. Ouers stel glad nie meer belang in die onderwys en opvoeding van hulle kinders op skool nie en kan met geen oorredingskrag meer daartoe beweeg word nie. Nou moet daar wetgewing kom wat die skool aan die ouers terugbesorg, volgens die ou bekende C.N.O.-beginsel van staatsondersteunde ouerskole. Asof daarmee die laksheid van die ouer genees sal wees! Ouers wil hiermee net die verantwoordelikbeid van hulle afskuiwe, en as die optrede van die Raad dan nie die gewenste ideaaltoestand skep nie, hulle die reg voorbehou om die skuld vir die mislukking netjies na buite te verplaas. Mens moet in hierdie tye versigtig wees om nie dieselfde dwaallig as die arme Kongolese te volg nie, natuurlik hier net op beskaafder en verhewener vlak. Hierdie Raad, of om die saak in sy breër implikasie te sien, die Republiek sal nie as sodanig hierdie probleme oplos of kan oplas nie. Hulle sal dit eers kan doen as hulle daarmee vorm gee aan ons aller strewe en bemoeienis.

Daar is egter ook 'n derde groep wat hierdie Onderwysraad wil gebruik om hulle strydmoegheid te beëindig deur sekere praktyke te bestendig en so te sanksioneer. Dit gaan hier om praktyke waarteen hulle nie meer die stryd kan volhou nie. Die moderne stroom met sy suigkrag word te sterk om verder met ons behoudende beginsels teruggehou te word. Self sien hulle darem nie kans om nou te kapituleer nie en samewerking met enersdenkendes lewer ook niks op nie want almal pak die stryd met aarseling aan. Die nuwe praktyke wat hulle aan ons opdring, lyk so aanloklik, asof ons dan maar gemaklik kan gaan terugsit en arms vou, sonder stryd, en tog sal bereik wat ons andersins so swaar voor sal moet stry. Die veranderinge gaan egter teen die tradisie en eeuelange gevestigde praktyke in, sodat hulle onder die huidige bedeling weinig kans het. As ons nou die Republiek kry en daarmee saam die Nasionale Onderwysraad, kan „die winde van verandering' maklik die ommeswaai bewerkstellig. 
In die artikel van dr. J. L. du Plooy: "Riglyne vir die onderwys", (Koers, Junie 1960) word sekere veranderinge bepleit wat as voorbeeld van hierdie gesindheid beskou kan word. Ons wil daarop kortliks die aandag vestig, sonder om afbreuk te doen aan die baie waardevolle gedagtes wat in die artikel vervat is en sonder om te insinueer dat die skrywer juis die gedagtegang hierbo gestel, voorstaan. Moet ons die gesinsverbrokkeling waarvan die skrywer praat, nou maar as 'n voldonge feit aanvaar en daarvandaan begin beplan en so probeer om die kind te beveilig deur aan hom 'n gesinslose (en daarmee voorwaar ook 'n onveilige) opvoeding te gee? Moet ons nie juis alles in die werk stel om die gesinsverbrokkeling teë te gaan nie? Hoe kan ons nou bepleit dat die staat moet sorg vir 'n skool wat die kind die hele dag onder sy toesig hou, hom selfs van 'n middagmaal voorsien, sy tuiswerk en sy ontspanning behartig, hom seker ook nog weer by die huis besorg, soos hy hom by die huis gaan haal het? Die staat versorg die kind dan van 7 of 8 uur in die oggend tot 5 of 6 uur saans en besorg hom vir die nag aan die onbelangstellende en selfsugtige ouer, wat dan die versorging tydens die nag moet waarneem. Is dit dan nie juis wat die moderne ouer wil hê nie, om bedags onbesorg en onbekommerd die beroep te beoefen terwyl ander die spit moet afbyt? En hierdie ander sal heel gou hulle „huurlinge" word, dus die plek van die huidige ,kindermeid" moet inneem as die kinders te groot geword het vir haar sorg. Wie se beeld sal hierdie kind eendag in sy latere lewe vertoon, die van sy ouers of die van sy onderwysers? Mens vrees dat hy nog die een nog die ander sal vertoon, maar sal oorspring van die een na die ander soos dit hom pas: die tipiese wanaangepaste. Maar verder, waarom moet die kind saans tuis wees? Mag mens aanneem dat die moderne ouers dit graag so wil hê? Sal die kind dan nie maar weer verwaarloos as die ouers saans op sake of plesierjag wil gaan nie? Nooi ons nie daarmee die staat om hier ook die reddende hand uit te steek terwille van die kind nie? Mens voorsien dat op hierdie wyse biologiese ouers en 'n ouer-staat bevorder word. Lyk dit nie of ons naderhand die weg van totalitêre state volg en veel in hierdie opsig by Rusland kan leer nie? En die Onderwysraad moet vir ons hierdie pragtige uitweg bewerkstellig, dan kan ons mos nie anders nie, dan is ons geregverdig en hoef nie meer te stry nie.

Maar hierdie tendens voer ons verder weg. Daar is mense wat die Raad wil gebruik om ons kinders al van vierjarige ouderdom af in die staat se kleurterskole te laat grootword, want die staat eis die moeders op vir openbare dienste. Mag 'n staat sy moeders „opeis' en dan 'n substituutmoeder voorsien in die vorm van creche's en kleuterskole? En as die staat tog sy moeders opeis, is dit seker ons plig om hom daarin te beveg waar hy besig is om selfmoord te pleeg. Ons sal langs hierdie weg 'n volk kweek wat geen ouerlike verantwoordelikheid meer ken nie. Hierdie kwaad vreet aan die wortel van ons bestaan, aan die gesondheid van die elementêre sel self, naamlik die gesin. 
Kan ons nie liewers in die Onderwysraad die statutêre liggaam sien wat as mondstuk kan dien van ons stryd teen die gevaarlike tendense nie? Kan ons nie liewers ons Republiek sien nie as die staatsvorm waarin ons op die opvoedkundige terrein harder sal kan veg as ooit tevore om die behoud van die beginsels wat die grondslag van ons voortbestaan verteenwoordig?

Dis waar, tye het verander, omstandighede het verander, alles is besig om teen 'n geweldige tempo te verander. Daar moet aanpassing hieraan kom, ons gevestigde praktyke moet gewysig word om by die moderne eise aan te pas, ons moet modern word in die toepassing van ons middele by die opvoeding en onderwys van ons kinders. Maar ons mag nooit toelaat dat middele ons tot prysgawe van beginsels dwing nie. Ons het 'n reusetaak, want ons mag nie die weg van minste weerstand volg nie. Ons moet modern wees (die ware Calvinis is dit altyd!), dog met behoud van ons beginsels. Daarin mag geen modernisering plaasvind nie. Ander mense wat van ons verskil, die pragmatiste en die sosialiste byvoorbeeld, veg met hand en klou tot die bitter einde toe om die ganse stelsel so te hervorm dat hulle ideale daarin seëvier. Ons het ook daartoe 'n dure plig en 'n hoë roeping. En waar kan 'n mens 'n mooier doel en 'n hoër ideaal in die onderwys kry as juis die een wat ons huldig?

B. C. SCHUTTE. 